\title{
The assessment of clay buffers for isolating highly radioactive waste
}

\author{
T. Yang ${ }^{1,2}$, R. Pusch ${ }^{2}$, S. Knutsson ${ }^{2} \&$ L. Xiaodong ${ }^{1}$ \\ ${ }^{1}$ East China University of Technology, China \\ ${ }^{2}$ Luleå University of Technology, Sweden
}

\begin{abstract}
Great effort is put into finding optimal buffer clays for isolating highly radioactive waste (HLW) in countries utilizing nuclear energy. Different materials are required to provide a hydrologically and mechanically suitable surrounding of canisters with highly radioactive waste in repositories in crystalline rock. For shallow disposal the high hydraulic conductivity of the rock makes very dense smectite-rich clays necessary while for disposal in very deep holes the primary desire is to use smectitic clays with a potential to resist high temperatures. In both cases montmorillonite, with $\mathrm{Al}$ being a dominant lattice ion in the octahedral layer, is suitable, but saponite with $\mathrm{Mg}$ as the dominant octahedral constituent can be preferable for deep disposal. For both concepts the use of smectitic mud is an option for supplying the buffer with water from start and for controlling the hydration rate.
\end{abstract}

Keywords: high-level radioactive waste ( $H L W), H L W$ disposal in very deep holes (VDH), buffer clay, hydration.

\section{Introduction}

The multibarrier principle has been followed when countries utilizing nuclear energy worked out concepts for disposal of high-level radioactive waste. Some of them have considered the repository rock to be the most important barrier followed by the waste canisters and the canister-embedding substance, clay or concrete. Today the order tends to be changed since the isolating function of crystalline host rock is being questioned because of its complexity and sensitivity to seismic and tectonic impact and of the uncertainty in structural and hydrological characterization. For large repositories constructed underground, 
causing considerable structural changes, the role of the rock can be considered as mechanical protection of the chemical apparatus. For HLW disposal in very deep holes (VDH) [1] the largely undisturbed rock can, however, still be taken as a major barrier, firstly because the very salt groundwater at great depth will stay there and not bring possibly released radionuclides up to the biosphere and secondly because of the very low hydraulic conductivity of rock at depth. The design principles for the two concepts are illustrated in Figure 1.
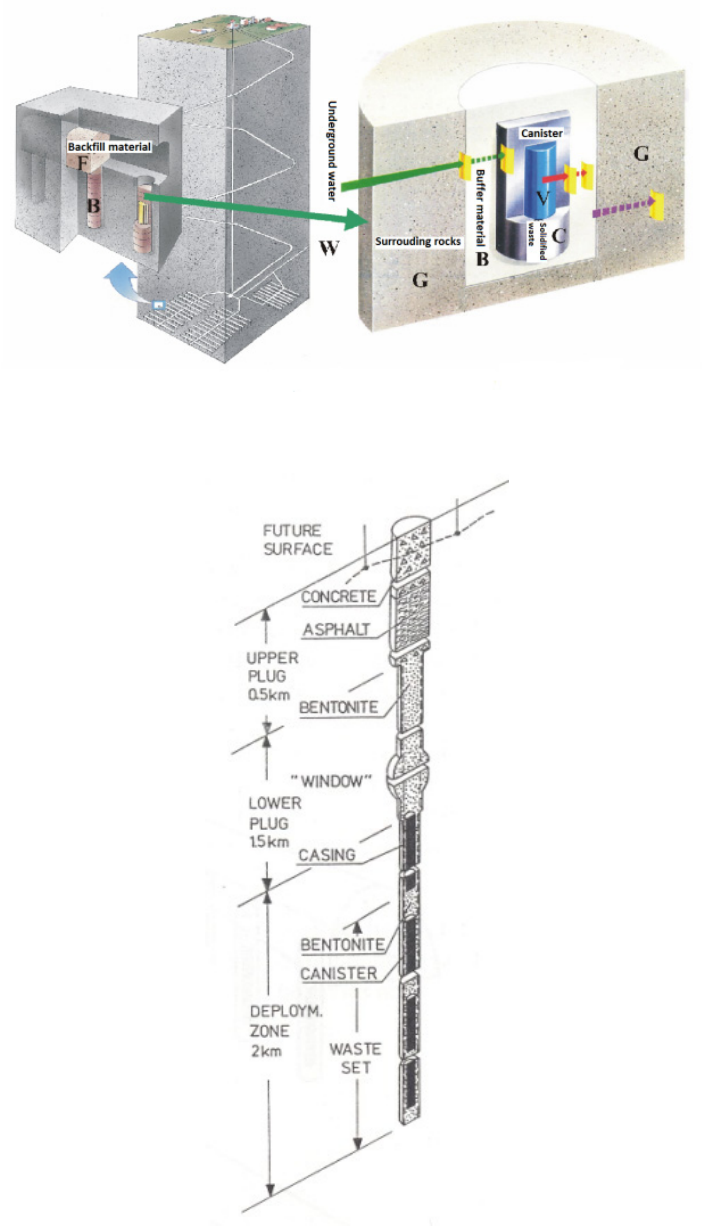

Figure 1: Upper: Chinese and Swedish concept for disposal of HLW at moderate depth $(500 \mathrm{~m})$ - B: Buffer material; C: Canister with V: Solid or solidified Waste; F: Backfill material; G: Surrounding rocks; W: Groundwater. Lower: Swedish VDH concept [2] (2000-4000 m). 
We will examine the function of different buffer clay types here with respect to their HLW-isolating potential, basing the study on the following performance criteria:

- The buffer clay must be tighter than the surrounding rock so that flowing groundwater is directed around and not through the buffer;

- The buffer must provide the canisters with a ductile embedment with sufficient bearing capacity;

- The physical properties must be preserved for a long, defined time, taken here as 100000 years.

\section{Buffer clay material candidates}

\subsection{Preparation of buffer}

The raw material for preparing clay buffer shall be well characterized smectitic clay that is dried and ground to the desired granular composition, which is different for compacting dense blocks and for preparing muds. Compression of blocks with low water content (4-6\%) under 100-150 MPa pressure gives a dry density of 1600 to $1900 \mathrm{~kg} / \mathrm{m}^{3}$. Muds are commonly prepared with a density at water saturation of 1100 to $1700 \mathrm{~kg} / \mathrm{m}^{3}$ (dry density 160 to $1110 \mathrm{~m}^{3}$ ). According to certain concepts smectite granules with a density similar to the blocks are used for preparing muds.

\subsection{Physical properties of buffers}

The most important physical property of smectite-rich buffers is the hydraulic conductivity, which is determined in the laboratory by compacting powder/granules in oedometer cells to the desired dry density and letting the sample saturate by sorbing water or solutions of specified composition. The swelling pressure exerted by the confined clay is recorded parallel to the saturation, which is followed by percolating the sample with the same type of fluid used for the saturation $[3,4,5]$. The recorded through-flow gives the hydraulic conductivity by applying Darcy's law.

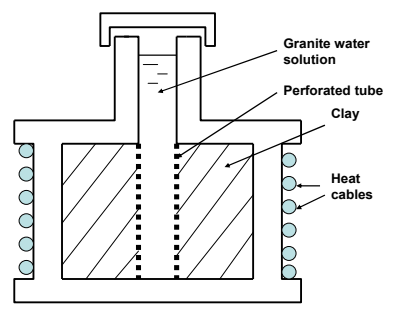

Figure 2: Example of hydrothermal cell in closed system, heated from outside and cooled by the water in the perforated tube. Radial thickness and height of the clay were 12 and $40 \mathrm{~mm}$, respectively. 
The evolution of the clay at hydrothermal treatment, maintaining the sample in a closed or open system at predetermined temperature and water transport conditions, is evaluated by measuring the hydraulic conductivity and swelling pressure. Chemical and mineralogical analyses are included in such work $[3,6]$.

\subsection{Candidate buffer clays}

\subsubsection{Materials}

Smectites are commercially available in large quantities in different parts of the world and those considered to be of potential use as buffers are rich in montmorillonite (dioctahedral), saponite (trioctadhedral) and mixed-layer minerals (montmorillonite/chlorite/illite) with high montmorillonite content. Wyoming bentonite (American Colloid Co) is manufactured with a certain granulometry and known as MX-80 that is rich in montmorillonite with $\mathrm{Na}$ as dominant sorbed cation. It serves as an international reference buffer material and has an equivalent material termed GMZ in China [7].

Saponite, i.e. magnesium-rich smectite, is employed in the petroleum industry for preparing drilling muds for deep borings where the temperature can be well over $120^{\circ} \mathrm{C}[8]$.

Mixed-layer montmorillonite/muscovite clay, which has the advantage of being compressible to very high densities almost irrespective of the water content of the granules, and of having a hydraulic conductivity that is not very sensitive to variations in porewater salinity, can be considered as well. Friedland clay from northern Germany and the Danish Holmehus clay, having different montmorillonite contents, represent this type of clays.

\subsubsection{Properties}

Typical chemical, mineralogical and physical properties of the three major buffer candidate types, i.e. clays rich in montmorillonite, saponite and mixed-layer minerals are given in Tables 1, 2 and 3.

Table 1: Chemical composition of montmorillonite-rich MX-80[7] and GMZ [7] clays, and of saponite (Geo-Hellas, Greece), and the two mixed-layer clays Friedland (Frieton AG) and Holmehus (Dantonite AS), (weight percentages, \%) [9].

\begin{tabular}{|c|c|c|c|c|c|c|c|}
\hline Clay & $\mathrm{SiO}_{2}$ & $\mathrm{Al}_{2} \mathrm{O}_{3}$ & $\mathrm{Fe}_{2} \mathrm{O}_{3}$ & $\mathrm{CaO}$ & $\mathrm{MgO}$ & $\mathrm{K}_{2} \mathrm{O}$ & $\mathrm{Na}_{2} \mathrm{O}$ \\
\hline MX-80 & 63.8 & 19.8 & 5 & 3.1 & 3.2 & 1 & 2.8 \\
\hline GMZ & 69.2 & 14.4 & 3.1 & 1.3 & 3.3 & 0.8 & 2 \\
\hline Saponite & 55 & 12 & 11 & - & 10 & 0.5 & 0.1 \\
\hline $\begin{array}{l}\text { Mixed-layer clay } \\
\text { (FIM) } \\
\text { Mixed-layer clay } \\
\text { (Holmehus) }\end{array}$ & 53 & 18 & 5 & 07 & 4 & 4 & 0.5 \\
\hline
\end{tabular}


Table 2: $\quad$ Mineralogical composition of MX-80, GMZ, saponite and mixedlayer clays (weight percentages, \%) [7, 9].

\begin{tabular}{|c|c|c|c|c|c|}
\hline Minerals & MX-80 & GMZ & Saponite & $\begin{array}{l}\text { Mixed-layer } \\
\text { clay (FIM) }\end{array}$ & (Holmehus) \\
\hline $\begin{array}{l}\text { Smectite } \\
\text { Mixed-layer }\end{array}$ & 50 & 50 & 50 & - & - \\
\hline illite/smectite & - & - & - & 50 & 55 \\
\hline Palygorskite & - & - & $10-20$ & - & 5 \\
\hline Quartz & traces & traces & traces & traces & $10-15$ \\
\hline Muscovite & - & - & - & - & $10-20$ \\
\hline Kaolinite & - & - & - & traces & - \\
\hline Illite & traces & - & - & $10-20$ & - \\
\hline Chlorite & - & - & - & $5-10$ & 5 \\
\hline Silica & $5-10$ & $10-20$ & - & $10-20$ & - \\
\hline Feldspar & $5-10$ & traces & - & $5-10$ & 5 \\
\hline Gypsum & - & - & - & - & traces \\
\hline Jarosite & - & - & - & - & traces \\
\hline $\begin{array}{l}\text { Calcite } \\
\text { Content of } \\
\text { particles }<2 \mu \mathrm{m} \\
(\text { wt.\%) }\end{array}$ & $5-10$ & 90 & 80 & traces & 90 \\
\hline
\end{tabular}

Table 3: Hydraulic conductivity and swelling pressure of MX-80, GMZ, saponite and mixed-layer clays for typical densities at saturation and percolation with $3.5 \% \mathrm{CaCl}_{2}$ solution water saturation density $[7,9]$.

\begin{tabular}{lcccc}
\hline Samples & $\begin{array}{c}\text { Density } \\
\mathrm{kg} / \mathrm{m}^{3}\end{array}$ & $\begin{array}{c}\text { Dry density } \\
\mathrm{kg} / \mathrm{m}^{3}\end{array}$ & $\begin{array}{c}\text { Hydraulic } \\
\text { conductivity } \\
(K), \mathrm{m} / \mathrm{s}\end{array}$ & $\begin{array}{c}\text { Swelling } \\
\text { pressure }\left(p_{s}\right), \\
\mathrm{kPa}\end{array}$ \\
\hline MX-80 & 1800 & 1310 & $\mathrm{E}-10$ & 200 \\
MX-80 & 2000 & 1175 & $2 \mathrm{E}-13$ & 4700 \\
GMZ & 1788 & 1233 & $\mathrm{E}-11$ & 530 \\
Saponite & 1800 & 1175 & $4 \mathrm{E}-12$ & 1300 \\
Mixed-layer FIM & 1800 & 1392 & $4 \mathrm{E}-11$ & 280 \\
$\begin{array}{l}\text { Mixed-layer FIM } \\
\text { Mixed-layer }\end{array}$ & 2000 & 1175 & $2 \mathrm{E}-11$ & 1000 \\
Holmehus & 1800 & 1310 & $2 \mathrm{E}-11$ & 600 \\
$\begin{array}{l}\text { Mixed-layer } \\
\text { Holmehus }\end{array}$ & 2000 & 1175 & $8 \mathrm{E}-12$ & 2000 \\
\hline
\end{tabular}




\subsubsection{Long-term performance}

Hydrothermal experiments have been made on clay samples of GMZ, MX-80 and FIM clay material prepared by compaction of air-dry clay granules in cells under $1.3 \mathrm{MPa}$ pressure and saturated with distilled water and $3.5 \% \mathrm{CaCl}_{2}$, followed by exposing the cells to a thermal gradient of $15^{\circ} \mathrm{C}$ per centimetre by heating one end to $85-95^{\circ} \mathrm{C}$ for 8 weeks and keeping the opposite at $35^{\circ} \mathrm{C}$ by circulating $1 \% \mathrm{CaCl}_{2}$ solution through it $[6,7,10]$. The results are summarized in Tables $4 \mathrm{a}$ and $\mathrm{b}$, the latter representing an experiment with saponitic clay. A general observation is that the densities of the hot-end samples were higher than the cold-ends because of the consolidation caused by the early raised swelling pressure of the lastmentioned. One also sees that the difference in swelling pressure between the cold and hot end samples was smallest for the mixed-layer FIM sample. For the saponitic clay (Table 5) the average conductivities and swelling pressures for the cold and hot ends were less strongly affected. Determination of the compressive strength made separately showed that the compression at failure was smallest for the most heated montmorillonite-rich GMZ clay (1.5\%) and MX-80 clay (3.2\%), and largest for the montmorillonitepoor mixed-layer FIM clay $6.4 \%$. For virgin clay of the respective type the percentages were $6.7 \%, 6.4 \%$ and $3.5 \%$.

Table 4: $\quad$ Evaluated hydraulic conductivity $(K)$, swelling pressure $\left(p_{s}\right)$ and density $\left(\rho / \rho_{d}\right)$ for GMZ, MX-80 and FIM after the hydrothermal experiment and subsequent saturation with $3.5 \% \quad \mathrm{CaCl}_{2}$ solution $[6,7,10]$.

\begin{tabular}{cllllll}
\hline Property & \multicolumn{2}{c}{ GMZ } & \multicolumn{2}{c}{ MX-80 } & \multicolumn{2}{c}{ FIM } \\
\cline { 2 - 7 } & $\begin{array}{l}\text { Hot } \\
\text { end }\end{array}$ & $\begin{array}{l}\text { Cold } \\
\text { end }\end{array}$ & $\begin{array}{l}\text { Hot } \\
\text { end }\end{array}$ & $\begin{array}{l}\text { Cold } \\
\text { end }\end{array}$ & $\begin{array}{l}\text { Hot } \\
\text { end }\end{array}$ & $\begin{array}{l}\text { Cold } \\
\text { end }\end{array}$ \\
\hline$\rho / \rho_{d}$ & $1871 /$ & $1788 /$ & $1951 /$ & $1844 /$ & $1958 /$ & $1875 /$ \\
$\left(\mathrm{kg} / \mathrm{m}^{3}\right)$ & 1040 & 1233 & 1375 & 1310 & 1412 & 1392 \\
$K,(\mathrm{~m} / \mathrm{s})$ & $2.6 \mathrm{E}-11$ & $2.6 \mathrm{E}-11$ & $1.2 \mathrm{E}-11$ & $1.2 \mathrm{E}-11$ & $1.8 \mathrm{E}-11$ & $4.0 \mathrm{E}-11$ \\
$p_{s}(\mathrm{kPa})$ & 110 & 53 & 130 & 1140 & 430 & 280 \\
\hline
\end{tabular}

Table 5: $\quad$ Evaluated hydraulic conductivity $(K)$, swelling pressure $\left(p_{s}\right)$ and density $\left(\rho / \rho_{d}\right)$ for a saponitic (about 50\%) DA0464 sample from GeoHellas Co with an initial dry density of $1527 \mathrm{~kg} / \mathrm{m}^{3}$ after hydrothermal experiment and subsequent saturation with $3.5 \%$ $\mathrm{CaCl}_{2}$ solution $[6,7,9,10]$.

\begin{tabular}{lcc}
\hline & \multicolumn{2}{c}{ DA0464 } \\
\cline { 2 - 3 } Property & Hot end & Cold end \\
\hline$\rho / \rho_{d}$ & $1880 / 1380$ & $1800 / 1175$ \\
$\left(\mathrm{~kg} / \mathrm{m}^{3}\right)$ & & \\
$K,(\mathrm{~m} / \mathrm{s})$ & $\mathrm{E}-12$ to $7.0 \mathrm{E}-11$ & $4.0 \mathrm{E}-12$ to $8 \mathrm{E}-12$ \\
$p_{s}(\mathrm{kPa})$ & $1880-2000$ & 1170 to 1300 \\
\hline
\end{tabular}


The major conclusions from the test series can be summarized as follows.

- Montmorillonitic clay $(M X-80)$ : The swelling pressure of the most heated part had been reduced by about $90 \%$ and the hydraulic conductivity of this part was about 100 times higher than that of untreated MX-80 clay [10, 11$]$.

- Saponitic clay (Geo-Hellas, Greece): The swelling pressure of the coldest part caused some but rather small compression of the hot part of the samples in the saturation phase. The average hydraulic conductivity of the hot part was roughly 10 times higher than that of the cold part but on the same order of magnitude as for untreated saponite (Table 3), [9, 10].

- Mixed-layer clay (FIM): The swelling pressure of the most heated part had been reduced by about $50 \%$ while the hydraulic conductivity of the cold part was nearly the same as for untreated Friedland clay $[9,10]$.

Experience from the wide use of the mixed-layer clay (FIM) of smectite/muscovite type as the top and bottom liners of hazardous landfill shows that it has a relatively poor swelling ability and a relatively high hydraulic conductivity. The Holmehus clay has a higher montmorillonite content and performs in principle as MX-80 and GMZ.

\section{Selection of candidate buffer clay for different repository types}

\subsection{Conditions affecting the use of candidate buffers}

We will consider here the possibilities and limitations of using clays of montmorillonite-, saponite- and mixed layer clay type in repositories of KBS-3 and VDH types. Fair comparison and selection of primary buffer candidates require definition of the rock conditions, earth-quake risks and glaciation scenarios, which we will leave out here, however, and make assessments referring only to the impact of temperature for placement of canisters and buffers, and of long-term performance of the buffers.

Several of the commonly proposed concepts for disposal of highly radioactive waste (HLW) imply construction at medium depth (400-600 m) in granitic rock, which is excellent for constructing a stable repository since it provides effective mechanical protection of the waste. At this depth waterbearing fracture zones are frequent and must be avoided in the site selection process since they can undergo large deformations and cause failure of waste containers located in or near them. The effect of such events can be minimized by surrounding them with ductile, rather soft "buffer" clay. The softness gives a rather high hydraulic conductivity, which must be compensated by using very smectite-rich buffer.

The concept implying placement of HLW in very deep boreholes (VDH) where the rock has a low hydraulic conductivity and where the very salt, heavy groundwater is stagnant, makes the impact of temperature and salt concentration in the groundwater especially important. In the upper parts, down to about $2 \mathrm{~km}$, the temperature is lower than about $60^{\circ} \mathrm{C}$, while it will be $100-150^{\circ} \mathrm{C}$ between 2 and $4 \mathrm{~km}$ depth. Thus, in the upper parts it is preferable to use clay that is very 
tight while the buffer in the lower, hot part it does not have to be very lowpermeable but not very sensitive to high salt concentrations. At the placement the holes are kept filled with clay mud into which the supercontainers with clayembedded canisters are inserted. The mud, which replaces the original mainly salt water, shall be strongly thixotropic and soften at their placement and become stiff once they are on site. It consolidates by being exposed to the swelling pressure of the dense clay blocks that occupy the supercontainers, which also contain waste canisters in the lower part of the holes. For the buffer in the lower parts of the holes long-term physical stability is of primary importance.

\subsection{Assessment of candidate buffers for different repository types}

\subsubsection{General}

The hydration and maturation of the buffer clay in KBS-3V and its Chinese equivalent concept (Figure 1) and of the mud and dense clay components in VDH are quite different and affect their long-term chemical stability differently. For the aforementioned concepts, the water pressure will be relatively low and the inflow into the deposition holes low, which can delay water saturation by tens to hundreds of years. During this period the desiccated clay is exposed to at least $100^{\circ} \mathrm{C}$ and salt enrichment, dissolution and precipitation processes on the microstructural scale can reduce the expandability and self-healing ability of the ultimately water saturated clay, and also make it stiffer.

In the upper, sealed part of the VDH the temperature will range from about $15^{\circ} \mathrm{C}$ to $60^{\circ} \mathrm{C}$ causing no heat-induced changes of any of the potential buffer clay candidates and providing total tightness early after installation. In the deployment part, which will be heated to $150^{\circ} \mathrm{C}$ in its lowest part, mineralogical changes and less good isolation are expected [10, 12]. Montmorillonite is converted to (non-expansive) illite via mixed-layer smectite/illite minerals or by precipitation, and quartz is formed at a rate determined by the access to potassium and temperature. Cementation is caused by neoformed quartz and illite. Natural analogues from various parts of the world indicate that Tertiary and Ordovician bentonites exposed to about $130-160^{\circ} \mathrm{C}$ for a few thousand years have a significant part of their montmorillonite contents preserved, and a common belief is that this will also be the case for KBS-3V and VDH $[6,10,11]$. We will consider buffers with a density at saturation with Casalt water of $2000 \mathrm{~kg} / \mathrm{m}^{3}$ in this section.

\subsubsection{Preliminary ranking of buffer candidates for use in KBS-3V repositories and their Chinese equivalents}

The most important criterion for the buffer for use in medium-depth repositories of KBS-3V type is that it should be less hydraulically conductive than the rock surrounding the deposition holes. A number of experimental studies have demonstrated the excellent tightness and expandability of dense smectite-rich buffer under isothermal conditions and temperatures up to at least $100^{\circ} \mathrm{C}$, while exposure to temperature gradients and temperature of this and higher orders initiate early degradation $[6,10]$. 
The hydraulic conductivity of very dense montmorillonite-rich buffer clay is judged to be lower than the conductivity of the surrounding rock [10]. Montmorillonite, being strongly expandable, may be partly washed out during a major glaciation cycle when electrolyte-poor melt water can percolate the repository rock and maximize the expandability and dispersivity. However, the most practically important and counteracting process is stiffening by silicification causing a loss in expandability and ability to self-seal after seismically and tectonically induced disturbance $[6,10]$.

This risk is lower for saponite-rich clays. The experiments referred to in this paper indicate that they will be only slightly or moderately affected by the hydrothermal conditions due to low solubility, and homogeneous microstructure with few collapsible gel components. Such clays are therefore strong buffer candidates in HLW respositories.

The mixed-layer clay used in the hydrothermal experiments was only moderately affected, hence showing considerable chemical integrity. Mixedlayer clays must, however be rich in smectite for being sufficiently tight and the Holmehus clay should hence be higher ranked than the FIM clay. The most obvious but still moderate chemical and mineralogical changes of this latter clay in the hydrothermal experiments were an increase in silica content in the coldest part and precipitation of silicious minerals, gypsum and kaolinite in the most heated parts. It remains, however, to investigate if the more smectite-rich Holmehus clay behaves acceptably at hydrothermal testing.

In summary, using Table 3 as a basis of ranking the clays and considering also the chemical stability, which determines the risk of stiffening by precipitation of dissolved mineral particles, the most suitable buffer clay material is deemed to be saponite. The second best is very dense mixed-layer clays of FIM and possibly also Holmehus types, while montmorillonite-rich clay, represented by MX-80 type clays, has the lowest ranking. The differences are small, however, and the often significant content of certain accessory constituents that can promote canister corrosion, like sulphur-bearing minerals, needs to be determined and assessed.

\subsubsection{Preliminary ranking of buffer candidates for use in VDH}

The high-temperature conditions in most of the deployment zone calls for a buffer that is chemically and mineralogically stable and that will not undergo significant loss of expandability and only moderate increase in hydraulic conductivity in a 100000 year perspective. The hydrothermal test project referred to indicates that saponite-rich clay is the best buffer candidate.

\section{Discussion and conclusions}

Two basically different concepts for the disposal of highly radioactive waste are the often cited KBS-3 method, being a candidate also for Chinese authorities, and a concept for deep waste placement termed VDH. The formerly mentioned implies HLW disposal at 400-600 m depth in rock, and at a 2-4 km depth for the latter. 
There are different buffer criteria for the two disposal concepts. For the one implying disposal of HLW at medium depth (400-600 m) in granitic rock, the buffer clay should have a sufficient swelling pressure and a lower hydraulic conductivity of the buffer clay than of the surrounding rock. This is fulfilled by the montmorillonite-rich clays MX-80 and GMZ. For the upper part of VDH this conclusion is valid as well. For the lower part of VDH where the rock is tighter, the buffer clay does not have to be as low permeable as for the upper part but it should still be low and not very sensitive to high salt concentrations. The most important property is a high mineralogical stability, which is fulfilled by saponite-rich clay with a density of at least $2000 \mathrm{~kg} / \mathrm{m}^{3}$. Very dense mixed-layer clays of the Holmehus type are expected to serve acceptably in the upper part of VDH holes and those of FIM type may be good enough in the deeper part provided that the density is very high and that smectite-rich mud is used.

\section{References}

[1] Pusch, R, Ramqvist, G, Knutsson, S, Hatem, M., The concept of highly radioactive waste (HLW) disposal in very deep boreholes in a new perspective. Earth Science and Geotechnical Engineering, 2(3), pp. 1-24, 2012.

[2] Pusch, R., Waste Disposal in Rock, Developments in Geotechnical Engineering, Elsevier Publ. pp. 76-89, 1994.

[3] Pusch, R., The Buffer and Backfill Handbook, Part 2: Materials and techniques, Swedish Nuclear Fuel and Waste Management Co (SKB) Technical Report TR-02-12. SKB, Stockholm, pp. 113-153, 2001.

[4] Yong, R. N., Pusch, R., Nakano, M., Containment of High-Level Radioactive and Hazardous Solid Wastes with Clay Barriers. Spon Press, London \& New York, pp. 237-303, 2010.

[5] Dixon, D.A., Graham, J., Gray, M.N., Hydraulic conductivity of clays in confined tests under low hydraulic gradients. Canadian Geotechnical Journal, Vol. 36, pp. 815-825, 1999.

[6] Pusch, R., Yong, R.N., Microstructure of Smectite Clays and Engineering Performance, SPON Research, Taylor \& Francis, London and New York. pp. 107-136, 2006.

[7] Xiaodong, L. Prikryl, R., Pusch, R., THMC-testing of three expandable clays of potential use in HLW repositories, Applied Clay Science, vol. 52, pp. 419-427, 2011.

[8] Gueven, N., Longevity of bentonite as buffer material in a nuclear waste repository, Engineering Geology, vol. 28, pp. 233-247, 1990.

[9] Kasbohm, J., Pusch, R., Nguyen-Thanh, L., Lab-scale performance of selected expandable clays under HLW repository conditions, Environment Earth Science, vol. 69, pp. 2569-2579, 2013.

[10] Pusch, R., Geological Storage of Radioactive Waste, Springer-Verlag, Berlin, Heidelberg, pp. 180-191, 2008. 
[11] Pusch, R., Karnland, O., Lajudie, A., Decarreau, A., $M X-80$ exposed to high temperatures and gamma radiation, SKB Technical Report TR-93-03. SKB, Stockholm, 1993.

[12] Herbert, H.-J., Kasbohm, J., Sprenger, H., Fernández, A.M., Reichelt, C., Swelling pressures of MX-80 bentonite in solutions of different ionic strength, Physics and Chemistry of the Earth, vol. 33, pp. 327-342, 2008. 